American Journal of Biochemistry and Biotechnology 3 (3): 110-113, 2007

ISSN 1553-3468

(C) 2007 Science Publications

\title{
Stabilization of Tyrosinase-Bovine Serum Albumin Crystals by Glutaraldehyde
}

\author{
${ }^{1}$ Norouzian D., ${ }^{1}$ Akbarzadeh A., ${ }^{2}$ Abnosi M.H., ${ }^{1}$ Atyabi S.M., ${ }^{1}$ Farahngi A., ${ }^{1}$ Mehrabi M.R. \\ and ${ }^{3}$ Eslamifar A. \\ ${ }^{1,3}$ Pilot Biotechnology and Electron Microcopy Departments, Pasteur Institute of Iran, Tehran 13164, Iran \\ ${ }^{2}$ Biology Department, Arak University, Arak, Iran
}

\begin{abstract}
Tyrosinase and bovine serum albumin were co-crystallized by saturated ammonium sulfate solution(65\%) and 20\% polyethylene glycol ( PEG) 6000 and n-propanol as co-solvents .The obtained crystals were cross linked by glutaraldehyde solution $(1 \% \mathrm{v} / \mathrm{v})$. Polyethylene glycol 6000 was found to be better co-solvent than n-propanol. The developed biocatalyst could be recycled 6 times without further loss of tyrosinase activity. No loss of activity of cross linked tyrosinase -bovine serum albumin crystals was observed upon storage of the developed CLECs at refrigerator for six months.
\end{abstract}

Key words: Tyrosinase, bovine serum albumin, PEG 6000, n-propanol, crystallization, glutaraldehyde, stability

\section{INTRODUCTION}

Tyrosinase is a biocatalyst (EC 1.14.18.1) containing two atoms of copper per active site with mono-oxygenase activity that is responsible for the biosynthesis of melanins and other polyphenolic compounds ${ }^{[1]}$. Mushroom tyrosinase as a biocatalyst, in the presence of ascorbic acid ${ }^{[2]}$, has been employed to produce valuable compounds like hydroxytyrosol (an anti oxidant), 1-dopa (a drug used in the treatment of Parkinson's disease $)^{[3-5]}$. Other compounds like coumestrol and caffeic acid are reported to be produced by such biocatalyst ${ }^{[6,7]}$. Lenhart et. al. ${ }^{[8]}$ and Aberg et. $a l^{[9]}$ used tyrosinase for biocatalytic grafting of phenolic moieties or protein onto chitosan and eventually the modified chitosan could be used as hydrogels for skin substitutes ${ }^{[10]}$, adhesives ${ }^{[11]}$, matrices for drug delivery and for tissue engineering ${ }^{[12,13]}$. The enzymatic conversion of substrate to product under mild conditions has made the enzymes of prime importance to be used in biotechnological processes. Most of the enzymatic or biocatalytic processes occur in environmentally mild conditions with specificity and efficiency. There are obstacles in employing biocatalysts in enzyme catalysed processes, the major problems in such processes are biocatalyst instability and reuse of it in processes leading to conversion/synthesis of substrates/products .To circumvent such obstacles and in view of bioengineering advances, biocatalysts could be stabilized/immobilized due to following two main reasons.
* Easy separation of the enzyme from the product that simplifies enzyme application and permits reliable and efficient technology.

* Enzyme reuse provides number of cost advantages that are often an essential prerequisite for establishing an economically viable enzyme catalyzed processes $^{[14]}$.

Tyrosinase has been immobilized to convert 1tyrosine to 1-dopa in the presence of ascorbic acid that the later substance inhibits the conversion of 1-dopa to quinone ${ }^{[15-19]}$ and removal of phenols from the industrial wastewater ${ }^{[20,21]}$. Furthermore, tyrosinase is also immobilized in order to construct biosensors for the quantification of phenol and related compound in the environment ${ }^{[22]}$. Cross linked enzyme crystals (CLECs) have several characteristics that confer significant advantages over conventional enzyme immobilization methods like enhanced temperature stability, absence of an inert support, catalysis under harsh conditions such as temperature, $\mathrm{pH}$ and organic solvents. The insoluble nature of CLECs facilitates easy separation of the enzyme from the reaction mixture which increases the reuse efficiency of the enzyme [23]. Immobilization/stabilization of tyrosinase by crosslinking crystallized tyrosinase and bovine serum albumin complex is a method employed to develop a biocatalyst, which transforms 1-tyrosine in the presence of ascorbic acid to 1-dopa.

\section{MATERIALS AND METHODS}

Tyrosinase, bovine serum albumin (fraction V) and glutaraldehyde were purchased from Sigma. L-

Corresponding Author: $\quad$ Norouzian, D., Pilot Biotechnology Department, Pasteur Institute of Iran, Tehran 13164, Iran 
Tyrosine, 1-dopa and ascorbic acid were procured from Merck. Other reagents used were of analytical grade.

Assay of tyrosinase activity: Tyrosinase activity was determined colorimetrically from the amount of 1-dopa produced by tyrosinase action on 1-tyrosine in the presence of ascorbic acid and molecular oxygen as reported by Munjal and Sawhney ${ }^{[24]}$. The reaction mixture contained $1 \mathrm{ml}$ of $2.5 \mathrm{mM}$ tyrosine and ascorbic acid in $0.05 \mathrm{M}$ phosphate buffer $\mathrm{pH} 7$ to which $0.1 \mathrm{ml}$ (or $0.1 \mathrm{~g}$ of stabilized tyrosinase-bovine serum albumin) of appropriately diluted tyrosinase solution was added .The reaction mixture was incubated at $25{ }^{\circ} \mathrm{C}$ for 25 minutes. To the above solution, $1 \mathrm{ml}$ of the following reagents were added: $2 \mathrm{M} \mathrm{HCl}, 2 \mathrm{M} \mathrm{NaOH}, 15 \%$ (w/v) sodium molybdate and finally $15 \%(\mathrm{w} / \mathrm{v})$ sodium nitrite.Absorbance was recorded at $\lambda 450 \mathrm{~nm}$ after $1 \mathrm{~h}$ against blank which contained inactivated free tyrosinase solution .Units of enzyme activity can be defined as the amount of enzyme that produces $1 \mu$ mole of 1-dopa in one minute under the above assay conditions, employing 1-tyrosine as the substrate. The protein content of free tyrosinase solution was measured by Lowry's method, using bovine serum albumin as standard.

Co-crystallization of tyrosinase and bovine serum albumin: Batch co-crystallization of tyrosinase and bovine serum albumin was carried out at refrigerator .To tyrosinase solution containing $0.356 \mathrm{mg} / \mathrm{ml}$ protein was added $2 \mathrm{mg} / \mathrm{ml}$ of bovine serum albumin (fraction V) to give a protein solution containing $2.356 \mathrm{mg} / \mathrm{ml}$. Ammonium sulfate at concentration of $65 \%$ saturation along with $20 \%$ polyethylene glycol 6000 or $20 \%$ npropanol as co solvents were added to tyrosinase solution containing bovine serum albumin (fraction V) at $4{ }^{\circ} \mathrm{C}$ separately. The mixtures were kept on magnetite stirrers overnight and they were then left in refrigerator.The obtained crystals from each mixture were assayed for tyrosinase activity as mentioned above. The obtained crystals from each reaction mixture were cross linked with $1 \%(\mathrm{v} / \mathrm{v})$ glutaraldehyde solution prepared in phosphate buffer $\mathrm{pH} 7$, for 3 hours at $4{ }^{\circ} \mathrm{C}$ separately. The cross linked crystals were washed several times with distilled water and assayed for tyrosinase activity.

\section{RESULTS AND DISCUSSION}

Tyrosinase and bovine serum albumin were cocrystallized due to low protein content of tyrosinase. The final concentration of bovine serum albumin in the enzyme solution was adjusted to $2 \mathrm{mg} / \mathrm{ml}$. N-Propanol and polyethylene glycol 6000 were separately used as co-solvents to crystallize the protein solution containing tyrosinase and bovine serum albumin .It was observed that PEG was a better co-solvent in crystallizing concomitantly tyrosinase and BSA complex, and the loss of activity of tyrosinase-BSA complex crystals cross linked with $1 \%$ glutaraldehyde using n-propanol was almost three times more than PEG as a co-solvent .There are reports indicting the use of single enzyme like chloroperoxidase, glucoamylase, subtilisin and penicillin $G$ acylase to be crystallized or aggregated and then cross linked with glutaraldehyde solution respectively ${ }^{[25,26,27,28]}$.

Table 1: Loss of tyrosinase activity during crystallization and postcrystallization processes

Activity of free tyrosinase

Activity of free tyrosinase after

$2.17 \mathrm{U} / \mathrm{ml} / \mathrm{min} \pm 0.057$

addition of BSA

Activity of tyrosinase-BSA complex $\quad 0.27 \mathrm{U} / \mathrm{g} / \mathrm{min} \pm 0.011$

crystals dissolved in buffer and dialyzed.

Activity of tyrosinase-BSA complex $0.093 \mathrm{U} / \mathrm{g} / \mathrm{min} \pm 0.007$

crystals after cross linking with

glutaraldehyde

Table 1 indicates the loss of tyrosinase activity during crystallization process of tyrosinase and BSA complex. Fig. 1 shows the scanning electron micrograph of the developed biocatalyst. CLECs are highly stable biocatalyst and this could be due to compactness of enzyme molecules almost to the theoretical limit, stabilization is a consequence of intense polar and hydrophobic interactions ${ }^{[29]}$.

The operational stability and storage stability of newly developed tyrosinase biocatalysts were studied. The operational stability was performed in batches containing $1 \mathrm{~g}$ of stabilized tyrosinase in a solution containing $5 \mathrm{mM} 1$ - tyrosine and ascorbic acid at $25^{\circ} \mathrm{C}$ and $150 \mathrm{rpm}$. Duration of each cycle was 2 hours, after each cycle the developed biocatalyst was separated from the reaction mixture by centrifugation at 4000 $\mathrm{rpm}, 4^{\circ} \mathrm{C}$ for $10 \mathrm{~min}$ and the crystals were washed with $0.05 \mathrm{M}$ phosphate buffer $\mathrm{pH}$ 7. The washed out crystals were checked for tyrosinase activity and protein content, negligible leakages of enzyme and protein in first 3 cycles were observed. During further cycles no loss in activity of developed biocatalyst could be seen (Fig. 2).

The enzyme was stored in $0.05 \mathrm{M}$ phosphate buffer $\mathrm{pH}$ 7 for 6 months at refrigerator and every month, the crystals were taken out to check the enzyme activity, during the storage no loss in enzyme activity could be detected. Tyrosinase and BSA complex were kept in the assay buffer containing $2.5 \mathrm{mM}$ ascorbic acid in order to determine tyrosinase action on tyrosine content of BSA in the formed crystalline complex. 


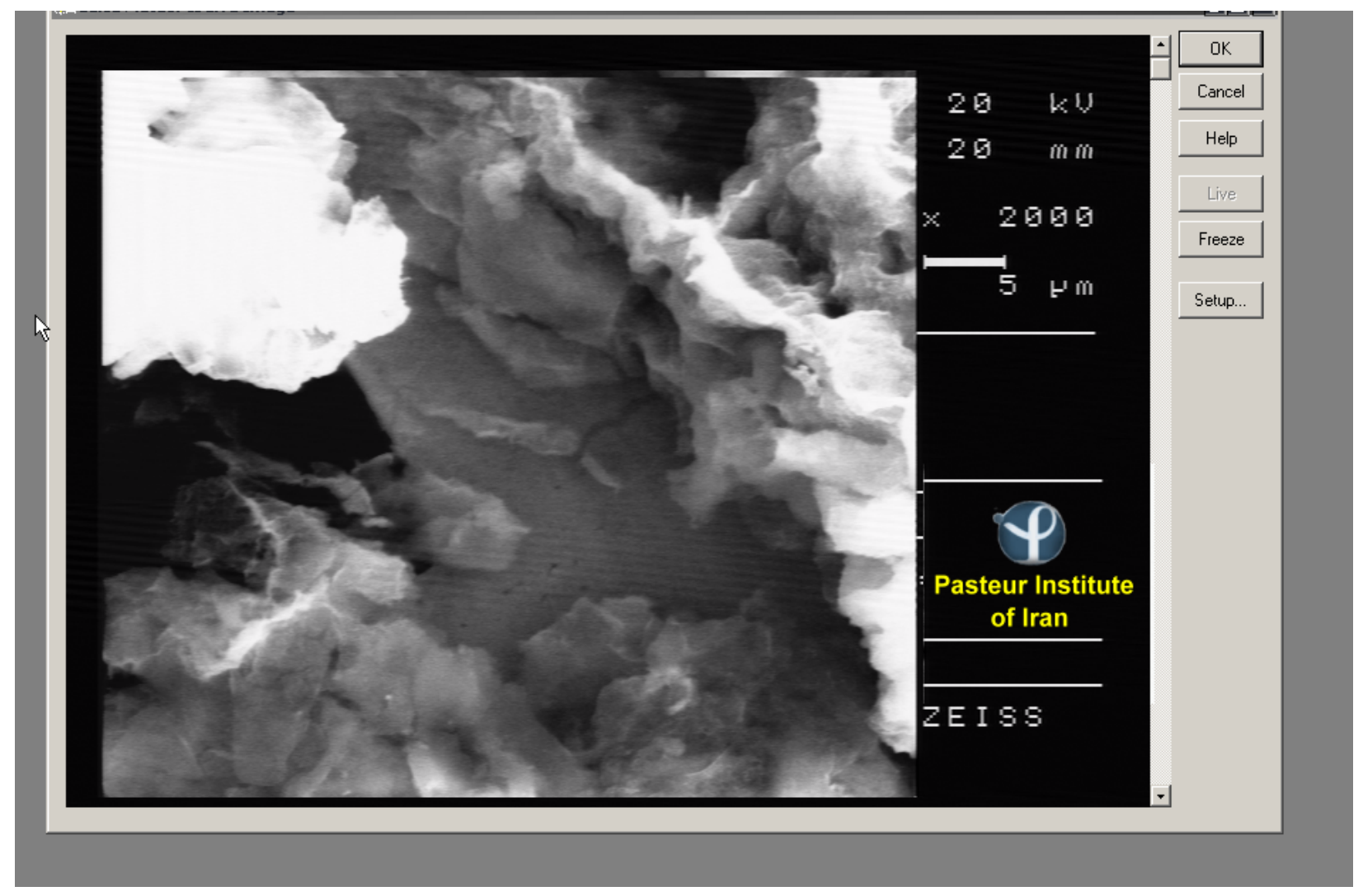

Fig. 1: Scanning electron micrograph of cross-linked tyrosinase-bovine serum albumin crystals

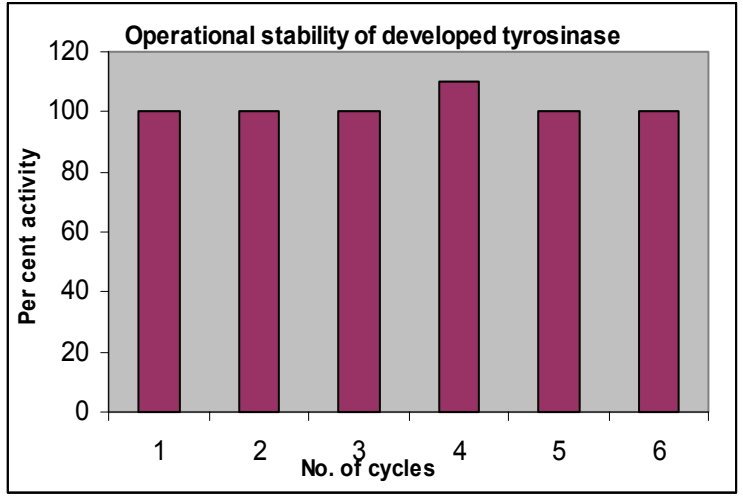

Fig. 2: Operational stability of cross-linked tyrosinase-bovine serum albumin crystals in batch operation

There was no tyrosinase activity in tyrosinase BSA complexes. Therefore, due to low protein content of tyrosinase, bovine serum albumin was used to enrich tyrosinase to develop highly stable cross-linked tyrosinase crystals containing bovine serum albumin.

\section{REFERENCES}

1. Luigi, B., G. Maurice van, B. Maurizio, W.J.W.T. Armand and W.C. Gerard, 2004. What are the structural features of the active site that define binuclear copper proteins function? Micron, 35: 143-145.

2. Sato, M., 1969. The conversion of $p$-cumaric acid to caffeic acid by phenolase with special reference to the role of ascorbic acid. Phytochem., 8: 353362.

3. Espin, J.C., C. Soler-Rivas, E. Cantos, F.A. TomasBarberan and H.J. Wichers, 2001. Synthesis of the antioxidant hydroxytyrosol using tyrosinase as biocatalyst. J. Agric. Food, 49: 1187-1193.

4. Neeru, M.S., K. Sushil and K.S. Surinder, 2003. A novel method for the immobilization of tyrosinase to enhance stability. Biotechnol. Appl. Biochem., 38: $137-141$.

5. Sikander, A., H. Ikram-ul and M.A. Qadeer, 2002. Novel technique for microbial production of 3, 4 dihydroxy phenyl l-alanine by mutant strain of Aspergillus niger. Electr. J. Biotechnol., 5: 118124. 
6. Kwang-Hoon, K., H. Min-Pyo, C. Sang-Sook, K. Youn-Tae and C. Sung-Hye, 2000. Purification and characterization of highly stable tyrosinase from Thermomicrobium roseum. Biotechnol. Appl. Biochem., 31: 113-118.

7. Halaouli, S., M. Asther, J.C. Sigoillot, M. Hamdi and A. Lomascolo, 2006. Fungal tyrosinase: New prospect in molecular characteristics, bioengineering and biotechnological applications. J. Appl. Microbiol., 100: 219-232.

8. Lenhart, J.L., M.V. Chaubal, G.F. Payne and T.A. Barbari, 1998. Enzymatic Modification of Chitosan by Tyrosinase. Enzyme in Polymer Synthesis. (Eds.) Kaplan, D.L. and G. Swift. Washington DC: American Chemical Society Symposium series, pp: 188-198.

9. Aberg, C.M., T. Chen, A. Olumide, S.R. Raghavan and G.F. Payne, 2004. Enzymatic grafting of peptides from casein hydrolysate to chitosan, potential for value added byproducts from food processing waste. J. Agric. Food. Chem., 52: 788793.

10. Kane, J.B., R.G. Tompkins, M.L. Yarmush and J.F. Burke, 1996. Burn Dressings. In Biomaterial Science: an introduction to materials in medicine ed. Ratner BD, Hoffman AS, Schoen FJ, Lemons JE. San Diego: Academic Press, pp: 360 -370.

11. Peppas, N.A. and J.J. Sahlin, 1996. Hydrogel as muco-adhesives and bio-adhesives materials: A review. Biomaterial, 17: 1553-1561.

12. Malapragada, K. and B. Narasiman, 1998. Drug delivery system .In Handbook of biomaterial evaluation ed. Von Recum AF. New York: Taylor and Francis, pp: 415-426.

13. Lee, K.Y. and D.J. Mooney, 2001. Hydrogel for tissue engineering. Chem. Rev., 101:1869-1879.

14. Norouzian, D., 2003. Enzyme immobilization: The state of art in biotechnology. Iranian J. Biotechnol., 1: 197-206.

15. Gayathri, S. and A.S. Bradley, 2002. L-Dopa production from tyrosinase immobilized on zeolite. Enzyme and Microbial Technol., 31: 747-753.

16. Pialis, P., H. Jimenz, C. Maria and A.S. Bradley, 1996. L-Dopa production from tyrosinase immobilized on nylon 6.6. Biotechnol. Bioeng., 51: 14-17.

17. Ho, P.Y., M.S. Chiou and A.C. Chao, 2003. Production of L-dopa by tyrosinase immobilized on modified polystyrene. Appl. Biochem. Biotechnol., 111: 139-152.
18. Carvalho, G.M.J., T.L.M. Alves and D.M.G. Freire, 2000. L- Dopa production by immobilized tyrosinase. Appl. Biochem. Biotechnol., 84-86: 321-325.

19. Seetharam, G. and B.A. Saville, 2002. L-Dopa production from tyrosinase immobilized on zeolite. Enzyme and Microbial Technol., 31: 747-753.

20. Krastanov, A., 2000. Removal of phenol from mixtures by co-immobilized laccase/tyrosinase and polyclar adsorption. J. Ind. Microbiol. Technol., 24: 383-388.

21. Ensuncho, L., M. Alvarez-Cuenca and R.L. Legg, 2005. Removal of aqueous phenol using immobilized enzymes in a bench scale and pilot scale three-phase fluidized bed reactor. Bioprocess Biosyst. Eng., 27: 185-191.

22. Seo, S.Y., V.K. Sharma and N. Sharma, 2003. Mushroom tyrosinase: Recent prospect. J. Agric. Food Chem., 51: 2837-2853.

23. Ciarán, Ó.F., 2003. Enzyme stabilization- recent experimental progress. Enzyme and Microbial Technol., 33: 137-149.

24. Munjal, N. and S.K. Sawhney, 2002. Stability and properties of mushroom tyrosinase entrapped in alginate, polyacrylamide and gelatin gels. Enzyme and Microbial Technol., 30: 613-619.

25. Noritomi, H., K. Koyama, S. Kato and N. Nagahama, 1999. Increased thermal stability of cross linked enzyme crystals of subtilisin in organic solvent. Biotechnol. Techniq., 12: 467-469.

26. Tholat EA, Jegan RJ, Laxmi BVB and Kizakoottu KJ. 2004. Cross-linked enzyme crystals of glucoamylase as a potent catalyst for biotransformations. Carbohydrate Res., 339: 10991104.

27. Dietmar H and Peter S. 1999. Cross-linked enzyme crystals. Current Opinion in Chemical Biology, 3: 35-38.

28. Cao L, van Rantwijk F and Sheldon RA. 2000. Cross-linked enzyme aggregates: A simple and effective method for the immobilization of penicillin G acylase. Organic Letter, 2 (10): 13611364.

29. Noritomi H, Koyama K, Kato S, and Nagahama N. 1999.Increased thermal stability of cross linked enzyme crystals of subtilisin in organic solvent. Biotechnology Techniques 12 : 467-469. 